УДК 378[016:81'243]:004

(C) Черненко А.В., 2019 p.

https://orcid.org/0000-0003-4097-6246

DOI: $10.34142 / 23128046.2019 .47 .15$

А. В. Черненко

\title{
ІНФОРМАЦЙНО-ЦИФРОВА КОМПЕТЕНТНІСТЬ МАЙБУТНІХ УЧИТЕЛІВ ІНОЗЕМНОЇ МОВИ ЯК КЛЮЧОВА ВИМОГА НОВОЇ УКРАЇНСЬКОЇ ШКОЛИ
}

Застосування інформащійно-комунікаиійних технологій в освітньому прочесі сьогодні є одним із головних інструментів забезпечення успіху Нової украӥнської школи. Важливість запровадження сучасних IКT в освітній прочес обумовлена необхідністю формування інформаційно-иифрової компетентності вчителів іноземної мови, яка визнана однією з ключових компетентностей, що визначає актуальність дослідження. Стаття присвячена проблемі формування однієї із важливих компетентностей вчителів іноземної мови - інформаційно-цифрової. Метою статті є аналіз використання вчителем іноземної мови інформачійно-комунікаційних технологій та вивчення їх впливу на формування інформаційно-циифрової компетентності. Для досягнення мети використано загальнонаукові методи теоретичного рівня: аналіз, синтез і систематизація праць авторів із проблеми дослідження інформачійно-иифрової компетентності; логікосистемний, проблемно-цільовий, порівняльний аналіз із метою теоретичного обтрунтування особливостей використання IКТ технологій. Результати дослідження полягають у низиі напрацювань. Розкрита кониепиія компетентнісного підходу в навчальному процесі на сучасному етапі реформування освітньої галузі. Виділено основні функиії використання інформаційно-комунікаційних технологій в освітньому процесі. Також запропонована класифікація засобів IКТ відповідно до їх застосування $у$ діяльності вчителів. Особлива увага в роботі приділена формуванню інформаційно-цифрової компетентності майбутніх учителів іноземних мов як основної складовою навчального прочесу. Описані характеристики навичок, необхідних для успішного формування інформаційно-циифрової компетентності та комплекс заходів щодо вивчення іноземних мов за допомогою IКТ. Особлива увага у роботі приділена використанню IKT на уроках іноземних мов, щзо дає нові можливості учням, а також підтримує вчителів у вирішенні окремих дидактичних завдань. Розглянуто переваги та труднощі використання IКТ на уроках іноземної мови.

Ключові слова: інформаційно-цифрова компетентність; інформаційно-комунікаційні технології; ичфрова грамотність, іноземна мова. 
Chernenko A. V. Information and digital competence of foreign language teachers as a key demand of New Ukrainian School. The use of information and communication technologies in the educational process today is one of the main tools for ensuring the success of New Ukrainian School. The importance of introducing modern ICT into the educational process is due to the need to the formation of the information and digital competence of foreign language teachers, which is recognized as one of the key competencies. It reflects the research topicality. The article is devoted to the problem of forming one of the important competences of foreign language teachers - information and digital.The purpose of the article is an analysis of the use of information and communication technologies by foreign language teacher and their influence on the formation of information and digital competence. To achieve the purpose the general theoretical scientific methods are used such as analysis, synthesis and systematization of researchers' works where the problem of the information and digital competence is described; logical-systemic, problem-targeted, comparative analyses as for theoretical basics of the peculiarities of ICT using. There are some research results. The competence approach concept in the educational process at a current stage of educational sphere reformation was revealed. The main functions of information and communication technology using in the educational process and possibilities of its successful using were mentioned. The ICT tools classification according to their application in teachers' activity was proposed. The formation of information and digital competence in foreign languages future teachers, as a core component in current educational process was indicated. The article contains the characteristics of skills necessary for the successful formation of information-digital competence and a set of activities for teaching foreign languages with the help of ICT. The particular attention was paid to the ICT using at foreign languages classes that gives new opportunities to pupils, as well as supports teachers to solve some didactic tasks. The ways of ICT using according to the need of the specific lesson were presented. Also the advantages and disadvantages of ICT using at foreign language lessons were discussed.

Keywords: information and digital competence; ICT tools; digital literacy, foreign language.

Вступ. В умовах тотальної інформатизації життедіяльності людини висуваються нові вимоги до освіти. У зв'язку 3 цим відбувається модернізація, постійні зміни освітнього процесу, що зазначено в концепції «Нова українська школа», яка обумовлює актуальність даного дослідження.

Різноманітні аспекти впровадження цифрових технологій у навчальний процес закладу освіти та пов'язані з цим формування та розвиток відповідних компетентностей є актуальними у світлі сучасного реформування освіти в Україні.

У зв'язку з сучасним реформуванням української освітньої галузі висуваються нові вимоги до освітян. Отже, концепція компетентнісного 
підходу в Україні є ключовою, яка висвітлюється в концепції «Нова українська школа». Згідно з сучасними змінами, термін «компетентність» трактують як інтегрований комплекс знань, навичок, цінностей, поглядів, мотивів та особистих якостей, що надають змогу успішно навчатись та професійно зростати.

Реформа Міністерства освіти і науки «Нова українська школа» (Bibik, 2018) визначає 10 ключових компетентностей, зміст яких визначає особистий розвиток, реалізацію, активну громадянську позицію, конкурентоспроможність та інклюзію, які здатні на протязі усього життя налаштувати на успіх та особисту реалізацію. Інформаційно-цифрова компетентність $є$ у складі ключових компетентностей, що визначає впевнене та критичне застосування цифрових технологій, а також знання інформаційної та медіа-грамотності, алгоритмічного мислення, знання основ програмування, здобуття навичок безпеки в Інтернеті та кібербезпеки, а також розуміння роботи з інформацією. (Konevshchynska \& Ovcharuk, 2018).

Для аналізу праць попередників, визначення основних аспектів досліджуваної проблеми, на наш погляд, необхідно проаналізувати ключовий термін «інформаційно-цифрова компетентність», а саме, його дві складові: «інформаційну компетентність» і «цифрову компетентність».

Дослідженню суті поняття «інформаційна компетентність» на сучасному етапі присвячено праці багатьох вітчизняних та зарубіжних учених, зокрема, праці В. Бикова (Bykov, 2010), I. Костікової (Kostikova, 2018), (Kostikova, Viediernikova, Holubnycha, \& Miasoiedova, 2019), Л. Пєтухової (Pietukhova, 2008), I. Роберт (Robert \& Samoilenko, 1998) та ін. Аналіз перерахованих праць показав, що під інформаційною компетентністю вчені розуміють пошук, перетворення, аналіз, а потім вже якісне використання інформації. Наприклад, Л. Пєтухова визначає, що інформаційна компетентність це - комплекс знань, умінь i навичок для пошуку, перетворення, передачі та використання інформації у різних сферах людської життєдіяльності (Pietukhova, 2008).

Щодо терміну «цифрова компетентність», єдиного тлумачення для визначення даного виду компетентності серед науковців немає: у більшості випадків використовується синонімічно два терміни: «цифрова компетентність» (digital competence) і «цифрова грамотність» (digital literacy). Як стверджує В. Биков, у обох випадках володіння цифровою грамотністю або компетентністю передбачає «впевнене та критичне використання доступних технологій інформаційного суспільства для повсякденного спілкування, роботи та відпочинку» (Bykov, 2010). 
Європейська рамка е-компетенцій (European e-Competence Framework) розглядає поняття «інформаційно-комунікаційної компетентності» в галузі освіти, яке охоплює знання відповідних педагогічних підходів і методів здійснення навчального процесу, а також наступні навички: аналіз вебресурсів та підбір адекватного навчального матеріалу, розробка навчальних планів та програм із використання IКТ, уміння аналізувати ефективність роботи та корегувати навчальний матеріал (E-Skills for the 21st Century: Fostering Competitiveness, Growth and Jobs, 2010). При цьому особлива увага приділяється підбору тих матеріалів та інструментів, які будуть мати високу результативність саме при використанні на заняттях із конкретної дисципліни.

Отже, сучасні науковці особливу увагу приділяють визначенню основних термінів, а також аналізу провідних компетенцій учителя іноземної мови. Проте, у нашому дослідженні основна увага приділятиметься визначенню функцій, показників інформаційно-цифрової компетентності; дидактичних завдань, розв'язанню яких вона сприяє; труднощів, які можуть виникати при формуванні такої компетентності.

Мета та завдання. Метою статті є аналіз використання вчителем іноземної мови інформаційно-комунікаційних технологій та вивчення їх впливу на формування інформаційно-цифрової компетентності. Завдання: визначити основні функції та показники інформаційно-цифрової компетентності вчителя 3 використання інформаційно-комунікаційних технологій (ІКТ) в освітньому процесі; проаналізувати застосування IКТ на уроках іноземної мови; розглянути переваги та труднощі використання IКТ на уроках іноземної мови.

Методи дослідження. Для досягнення мети, розв'язання окреслених завдань дослідження було використано загальнонаукові методи теоретичного рівня: аналіз, синтез і систематизація праць авторів із проблеми дослідження інформаційно-цифрової компетентності; логіко-системний, проблемноцільовий, порівняльний аналіз із метою теоретичного обгрунтування особливостей використання ІКТ технологій.

Результати. Цифрова компетентність, за визначенням В. Бикова, спирається на базові навички в галузі IКТ (Bykov, 2010): використання комп’ютерів для отримання, збору, обробки, оцінки, зберігання та обміну інформацією, а також спілкування в мережі Інтернет.

Інформаційно-комунікаційні технології (IKT) стають все більш важливими засобами для забезпечення якісної вищої освіти. Використання ІКТ впливає як на якість викладання, так і навчання. Проаналізувавши більш докладно існуючі погляди на застосування IКT в освітньому процесі, 
вважаємо, що у цій галузі використовують різні категорії IKT. Їх використовують для спілкування між керівництвом, викладачами та іноді студентами. У цьому плані ІКТ є платформою для плідної праці керівництва 3 кафедрами. По-друге, IКТ використовують серед викладачів задля проведення власних досліджень, підготовки до уроків, презентацій на уроках та оцінювання учнів. По-третє, ІКТ використовують студенти для організації власних досліджень, виконання завдань та спілкування з іншими студентами, викладачами та керівництвом закладів вищої освіти.

Згідно 3 появою новітніх інформаційно-комунікаційних технологій виникає потреба у більш доцільному та ефективному застосуванні вчителем іноземної мови сучасних технологій, оскільки це є інструментом вирішення як дидактичних, так і особистих завдань.

У науковій літературі визначають основні функції використання IКТ в освітньому процесі, які представлені наступним чином: розвинути освітні послуги та засоби масової інформації; забезпечити рівні можливості для отримання освіти та інформації; розвинути систему збору та обробки освітньої інформації; підтримати обмін досвідом та інформацією; розвинути технологічну грамотність та забезпечити дистанційну освіту; сприяти поліпшенню інноваційних педагогічних навичок. ІКТ допомагають учителю мотивувати учнів та розвивати інтерес до навчання (Desai, 2010).

Проаналізувавши науково-педагогічну літературу, пропонуємо наступну класифікацію IKT за доцільністю використання у діяльності вчителя: використання проекторів для презентації уроків (як засіб навчання, що удосконалює процес викладання); використання elibraries та електронних журналів для проведення власних досліджень (як інструмент пізнання навколишньої дійсності й самопізнання); використання програмного забезпечення, онлайн курсів, блогів, електронних форумів (як засіб розвитку особистості учня; як об'єкт вивчення в межах опанування певного предмета); використання електронних книг та журналів (як засіб інформаційнометодичного забезпечення); використання соціальних мереж (як засіб комунікації).

Дослідниця І. Роберт виділяє такі ключові показники інформаційної компетентності майбутнього вчителя, як: наявність загальних навичок використання інформаційно-комунікаційних технологій; встановлення інтерфейсу та програмного забезпечення; вміння створювати мультимедійні презентації 3 PowerPoint; використання електронних освітніх додатків; застосування можливостей пакету Microsoft Office для розробки дидактичних матеріалів із предметної галузі та робочих документів; наявність уміння 
обробляти графічні зображення, робота 3 базовими Internet-сервісами, технологіями та основами технології задля побудови web-сайтів.

Безперечно, формування інформаційно-цифрової компетентності у майбутніх учителів іноземної мови $є$ важливою складовою їхньої професійної підготовки. Майбутній учитель має бути здатним до пошуку, добору та аналізу новітніх цифрових ресурсів, сучасних розробок у своій професійній діяльності, обміну досвідом та знаннями 3 колегами за допомогою віртуальних освітніх платформ. Так, уміння майбутнього вчителя використовувати ІКТ у навчанні іноземної мови формує його інформаційноцифрову компетентність.

Використання цифрових технологій у викладанні іноземної мови змінює традиційні форми навчання та підвищує навчальну діяльності учнів, оптимізує засвоєння лексичного та граматичного матеріалу, а також допомагає подолати монотонність, яка притаманна на заняттях при формуванні мовної і мовленнєвої компетенцій учнів.

Отже, висвітлюючи питання IКТ, на думку А. Лавренчука, необхідно визначити їх важливі переваги, а саме: збереження, збільшення та порівняння значного обсягу інформації; супровідне зображення тексту; підключення до Інтернету, здійснення аудіо супроводу; використання відео та анімації; робота 3 додатками; створення власної інформації; створення закладок на екрані; включення ігрових компонентів; зручна навігація тощо (Lavrenchuk, 2013).

Загальновідомо, що Інтернет є одним із головних та корисних засобів для викладання іноземної мови. Вчителі можуть використовувати його для збору інформації, щоб удосконалити та урізноманітнити навчальні плани. Вони можуть підписатися на різноманітні розсилки, які пов'язані з IELTS, TOEFL та обмінюватися інформацією з іншими вчителями. Також учителя іноземної мови можуть передплачувати електронні журнали та слідкувати за новими тенденціями викладання англійської мови, знаходячи нові або цікаві публікації.

Засоби ІКТ надають можливість розв'язувати такі актуальні питання (за Т. Коваль), як: впроваджувати у навчанні здобутки новітніх інформаційних технологій; удосконалювати індивідуальну роботу учнів у інформаційному просторі, мережі Інтернет; удосконалювати освіту, прискорювати засвоєння шкільного курсу певного предмету, робити навчальний процес більш різноманітним (Koval, 2009).

Також слід зазначити, що, за I. Бученко (Buchenko, 2007), застосування IКT вчителем іноземної мови на уроках допомагає вирішувати ряд дидактичних завдань, зокрема: аудіювання (використовуючи аутентичні 
звукозаписи у мережі Інтернет); монологічне та діалогове мовлення (використовуючи проблемне обговорення питань); активний i пасивний словниковий запас (використовуючи лексику сучасної англійської мови, що відображає певний етап розвитку культури народу, соціального чи політичного устрою суспільства) (Buchenko, 2007).

На нашу думку, використання IКТ відкриває нові можливості як учням, так і допомагає вчителю розв’язати додатковий ряд дидактичних завдань, а came:

- $\quad$ створити максимально природне мовне середовище на занятті;

- $\quad$ більш повно реалізувати принцип наочності;

- $\quad$ поглибити знання 3 усіх видів мовленнєвої діяльності (усне мовлення, аудіювання, читання, письмо);

- розширити вокабуляр за допомогою лексики сучасної іноземної мови.

Безперечно, при підготовці до кожного уроку необхідно враховувати переваги використання IКТ (за Г. Швачич) (Shvachych, 2017), а саме:

- загальну мотивацію та зацікавленість у навчанні завдяки новітнім технологіям, що роблять форми роботи більш сучасними;

- індивідуальні форми навчання (кожен учень обирає свій режим роботи, який його задовольняє);

- використання цікавих форм подачі інформації, що активізує навчання завдяки змаганню учнів з гаджетами (комп'ютером, планшетом, телефоном);

- організацію творчої діяльності;

- формування інформаційного простору;

- прийняття швидких рішень у складній ситуації;

- забезпечення доступу учнів до банків інформації, можливості оперативно отримувати необхідну інформацію;

- удосконалення самостійної роботи учнів (Shvachych, 2017).

Використання вчителем іноземної мови IKT технологій надає багато переваг, а саме: можливість легко адаптувати навчальні матеріали до обставин та потреб учнів; IКТ дозволяє використовувати останні / щоденні новини, автентичні матеріали; можливість комбінувати / використовувати по черзі (основні) навички (текст та зображення, аудіо та відео, кліп), заняття стають більш цікавими, що сприяє залученню студентів до навчання; IКТ дозволяє зосередити увагу на одному конкретному аспекті уроку.

Отже, поряд із суттєвими перевагами використання IKT, учитель може зіткнутися 3 різними труднощами, які можуть з'явитися під час підготовки або проведення занять. Але головною проблемою є відсутність належного 
фінансування. Звідси з'являються наступі труднощі: неналежне оснащення необхідної матеріальної бази (комп’ютера, мультимедійного обладнання, комп'ютерних програм), обмежена кількість безкоштовних навчальних програм для майбутніх учителів, обмежена кількість безкоштовних курсів для вчителів, у яких ще не сформовані навички роботи 3 IKT, не відповідність комп'ютерних програм вимогам навчальної програми тощо.

Також використання IКТ на уроках вимагає від майбутнього вчителя досконалого володіння комп'ютером. Однак, не зважаючи на певні труднощі, використання IKT має значні переваги та перспективи, досягнути яких можна шляхом упровадження даних технологій на уроці для формування такої необхідної та сучасної інформаційно-цифрової компетентності майбутнього вчителя, як того вимагає «Нова українська школа».

Обговорення. Дослідження сучасних науковців, як-от Л. Пєтухова (визначення поняття «цифрова компетентність» у професійній діяльності викладача ВН3 (Pietukhova, 2008)), А. Лавренчук (використання IКТ технологій відповідно до потреб конкретного уроку (Lavrenchuk, 2013)), I. Роберт (визначення основних показників інформаційної компетентності майбутнього вчителя (Robert \& Samoilenko, 1998)), I. Костікова (навчання студентів англійської мови засобами сучасних технологій (Kostikova, 2018)), I. Бученко (застосування IКТ на уроках іноземної мови (Buchenko, 2007)) свідчать, що порівняльний аналіз отриманих нами даних повністю співпадає 3 результатами досліджень попередників, які вивчали це питання. Іншими словами, проведене нами дослідження підтверджує висновки інших науковців щодо необхідності формування інформаційно-цифрової компетентності у викладача за допомогою використання IКТ технологій.

Висновки. Отже, на сучасному етапі інформатизації суспільства все більшого поширення набуває питання формування інформаційно-цифрової компетентності майбутнього вчителя іноземної мови як ключової вимоги «Нової української школи».

Безперечно, інформаційно-цифрова компетентність $\epsilon$ важливою для сучасного вчителя іноземної мови. Він має вдало використовувати ІКТ на власних уроках, щоб вирішувати дидактичні завдання. Сучасна освіта має сприяти формуванню у майбутнього вчителя іноземної мови інформаційноцифрової компетентності, вчитель має вільно орієнтується у світовому інформаційному просторі, використовуючи сучасні IКТ, які активно впроваджуються в процес навчання іноземної мови. Застосування IКТ дозволяє формувати інформаційно-цифрову компетентність майбутнього вчителя іноземної мови, реалізувати ідеї індивідуалізації та диференціації 
навчання на уроці, що сприяє оновленню засобів сучасної системи освіти України.

Перспективи подальших розвідок у даному напрямі полягають у визначенні структури і складників інформаційно-цифрової компетентності майбутнього вчителя іноземної мови.

\section{ЛIТЕРАТУРА:}

Desai, S. (2010). Role of Information Communication Technologies in Education. Proceedings of the $4^{\text {th }}$ National Conference; INDIA. Computing for Nation Development. Retrieved from

http://webcache.googleusercontent.com/search?q=cache:http://ijrar.com/upload_issue/ijra r_issue_1390.pdf

E-Skills for the 21st Century: Fostering Competitiveness, Growth and Jobs (2010). European Ecompetence Framework. Version 2.0. Retrieved from www.ecompetences.eu.

Kostikova, I. I. (2018). Information and communication technologies in students' language learning. International Journal of Education and Science, 1(1-2), 7-14.

Kostikova, I., Viediernikova, T., Holubnycha, L., \& Miasoiedova, S. (2019). The CompetencyBased Approach to Passing First Certificate in English. Revista Romaneasca pentru Educatie Multidimensionala, 11(1), 117-130.

Биков В.Ю. Сучасні завдання інформатизації освіти [Електронний ресурс]. Інформаційні технологіï $і$ засоби навчання. 2010. № 1 (15). https://journal.iitta.gov.ua/index.php/itlt.

Бученко I. В. Комп'ютеризація навчання - свідчення професійної майстерності педагога. К. : Інститут післядипломної педагогічної освіти, 2007. 192 с.

Використання інформаційно-комунікаційних технологій на уроках іноземної мови: тематичний збірник праць. За заг. редакцією А. О. Лавренчука. Рівне : РОІППО, 2013. 29 c.

Коваль Т. І. Підготовка викладачів вищої школи: інформаційні технології у педагогічній діяльності: навч.-метод. посіб. К.: Вид. центр НЛУ, 2009. 380 с.

Нова українська школа: порадник для вчителя. За заг. ред. Н. М. Бібік. К : Літера ЛТД, 2018. $160 \mathrm{c}$.

Пєтухова Л. Є. Інформатична компетентність майбутнього фахівця як педагогічна проблема. Комп 'ютер у школі та сім'ї. 2008. № 1. С. 3-5.

Роберт И. В., Самойленко П. И. Информационные технологии в науке и образовании. М.: ШколаПресс, 1998. 178 с.

Цифрова компетентність сучасного вчителя нової української школи: зб. тез доповідей учасників всеукр. наук.-практ. семінару (Київ, 28 лютого 2018 р.). За заг. ред. О. Е Коневщинської, О. В.Овчарук. К. : Інститут інформаційних технологій і засобів навчання НАПН України, 2018 - 61 с.

Швачич Г.Г. Сучасні інформаційно-комунікаційні технології: Навчальний посібник. Дніпро: НМетАУ, 2017. 230 с.,

\section{REFERENCES:}

Bibik, N. M. (Ed.) (2018) Nova ukrainska shkola: poradnyk dlia vchytelia [New Ukrainian School: Teacher Advisor]. Kyiv : Litera LTD. 160 p. (in Ukranian).

Buchenko, I. V. (2007). Kompiuteryzatsiia navchannia - svidchennia profesiinoi maisternosti pedahoha. [Computerization of learning is a testament to the teacher's professional skill] K.: Instytut pisliadyplomnoi pedahohichnoi osvity, 192 p. (in Ukranian).

Bykov, V. Iu. (2010). Suchasni zavdannia informatyzatsii osvity. [Modern tasks of informatization of education] Informatsiini tekhnolohii $i$ zasoby navchannia. No.1 (15). Retrieved from https://journal.iitta.gov.ua/index.php/itlt. (in Ukranian). 
Desai, S. (2010). Role of Information Communication Technologies in Education. Proceedings of the $4^{\text {th }}$ National Conference; INDIA. Computing for Nation Development. Retrieved from

http://webcache.googleusercontent.com/search?q=cache:http://ijrar.com/upload_issue/ijra r_issue_1390.pdf

E-Skills for the 21st Century: Fostering Competitiveness, Growth and Jobs (2010). European Ecompetence Framework. Version 2.0. Retrieved from www.ecompetences.eu.

Konevshchynska, O. E. \& Ovcharuk, O. V. (Ed) (2018, February 28) Tsyfrova kompetentnist suchasnoho vchytelia novoi ukrainskoi shkoly [Digital competence of the modern teacher of the new Ukrainian school]: zb. tez dopovidei uchasnykiv vseukr. nauk.-prakt. seminaru Kyiv: Instytut informatsiinykh tekhnolohii i zasobiv navchannia NAPN Ukrainy, p. 61 (in Ukranian).

Kostikova, I. I. (2018). Information and communication technologies in students' language learning. International Journal of Education and Science, 1(1-2), 7-14,

Kostikova, I., Viediernikova, T., Holubnycha, L., \& Miasoiedova, S. (2019). The CompetencyBased Approach to Passing First Certificate in English. Revista Romaneasca pentru Educatie Multidimensionala, 11(1), 117-130.

Koval, T. I. (2009). Pidhotovka vykladachiv vyshchoi shkoly: informatsiini tekhnolohii u pedahohichnii diialnosti [Training of high school teachers: information technologies in pedagogical activity]. K.: Vyd. tsentr NLU. 380 p. (in Ukranian).

Lavrenchuk, A. (Ed.) (2013) Vykorystannia informatsiino-komunikatsiinykh tekhnolohii na urokakh inozemnoi movy [Use of information and communication technologies in foreign language lessons]: tematychnyi zbirnyk prats. Rivne: ROIPPO. 29 p. (in Ukranian).

Pietukhova, L. Ie. (2008). Informatychna kompetentnist maibutnoho fakhivtsia yak pedahohichna problema. [Informative competence of the future specialist as a pedagogical problem]. Kompiuter u shkoli ta simi. 1. pp. 3-5. (in Ukranian).

Robert, Y. V. \& Samoilenko, P. Y. (1998). Ynformatsyonnыe tekhnolohyy v nauke y obrazovanyy. [Information Technology in Science and Education]. Moskva : ShkolaPress, 178 p. (in Russian).

Shvachych, H. H. (2017). Suchasni informatsiino-komunikatsiini komunikatsiini tekhnolohii. [Modern information and communication technologies]. Dnipro: NMetAU, 230 p. (in Ukranian).

\begin{tabular}{|c|c|}
\hline $\begin{array}{c}\text { Інформація про автора: } \\
\text { Черненко Анастасія Володимирівна: }\end{array}$ & $\begin{array}{l}\text { Information about th } \\
\text { Chernenko Anastasiia Voloc }\end{array}$ \\
\hline ORCID: https://orcid.org/0000-0003-4097- & ORCID: \\
\hline 6246; аспірантка кафедра загальної педагогіки і & 6246; PhD Student of Department of General \\
\hline 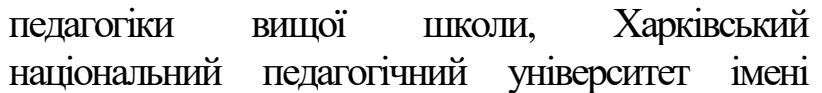 & $\begin{array}{l}\text { Pedagogy and Higher School Pedagogy, } \\
\text { H. S. Skovoroda }\end{array}$ \\
\hline $\begin{array}{l}\text { Г. С. Сковороди, вул. Валентинівська, } \\
\text { м. Харків, Україна } 61000\end{array}$ & $\begin{array}{l}\text { Pedagogical University, Valentynivska street, } \\
\text { 2, Kharkiv, Ukraine } 61000\end{array}$ \\
\hline ma & $2-101$ \\
\hline
\end{tabular}

Цитуйте цю статтю як: Черненко А. В. Інформаційно-цифрова компетентність майбутніх учителів іноземної мови як ключова вимога Нової української школи. Теорія та методика навчання та виховання. 2019. № 47. С. 169-178.

DOI: $10.34142 / 23128046.2019 .47 .15$

Дата надходження статті до редакції: 21.10.2019

Стаття прийнята до друку: 04.11.2019 